\title{
CORRELATION BETWEEN THE USE OF ALBUMIN INFUSION AND CONCENTRATIONS OF SERUM ALBUMIN, PROINFLAMMATORY CYTOKINES (TNF- $\alpha$, IL6) AND SOFA SCORE IN SEPTIC PATIENTS
}

\author{
Arie Utariani ${ }^{1}$, Budi Prasetyo ${ }^{1}$, Jusak Nugraha ${ }^{2}$ \\ ${ }^{1}$ Department of Anesthesiology \& Reanimation, ${ }^{2}$ Department of Clinical Pathology, Dr Soetomo Hospital, \\ Faculty of Medicine, Universitas Airlangga, Surabaya
}

\begin{abstract}
ABSTRAK
Sepsis masih merupakan masalah utama penyebab tingginya morbiditas dan mortalitas pada pasien yang dirawat di ruang perawatan intensif. Pada kondisi sepsis, terjadi perubahan distribusi albumin pada kompartemen intravaskuler dan ekstravaskuler, sehingga terjadi hipoalbumin. Penggunan albumin pada pasien sepsis dari beberapa penelitian yang telah dilakukan masih kontroversial. Menganalisa hubungan penggunaan infus albumin dengan perubahan kadar albumin, sitokin dan SOFA score pada pasien sepsis di ruang rawat intensif RSUD dr. Soetomo. Desain dari penelitian ini adalah observasional longitudinal prospektif. Penelitian dilakukan di ruang rawat intensif atau ICU RSUD dr. Soetomo dalam periode Februari 2015. Dari kriteria inklusi dan eksklusi yang ditentukan, didapatkan subyek penelitian sebanyak 15 orang. Kemudian dilakukan pemeriksaan kadar albumin serum dan sitokin proinflamasi serta penilaian SOFA score. Selanjutnya dilakukan uji statistik dengan metode uji ANOVA. Pemberian infus albumin mempunyai korelasi positif dengan peningkatan kadar albumin serum dan korelasi negatif dengan kadar IL6, TNF- $\alpha$ dan SOFA score. Selain itu juga didapatkan adanya korelasi antara perubahan kadar albumin dengan perubahan kadar IL6(p<0.01) dan perubahan SOFA score ( $p<0.05)$. (FMI 2016;52:310-315)
\end{abstract}

Kata kunci: sepsis, hipoalbumin, sitokin pro inflamasi, SOFA score

\begin{abstract}
Sepsis is a major problem causing high morbidity and mortality in patients who hospitalized in intensive care. In sepsis, there is a change in the distribution of albumin in the intravascular and extravascular compartment, so hipoalbumin is occured. Using albumin in septic patients from several studies that have been done are still controversial. Analyzing albumin infusion with changes in levels of albumin, cytokines and SOFA score in septic patients in intensive care dr. Soetomo. The design of this study is a prospective longitudinal observational. The study was conducted in the intensive care unit or ICU dr. Soetomo in February 2015. The inclusion and exclusion criteria were determined that obtained 15 research subjects. They were examined with serum albumin and proinflammatory cytokines as well as evaluating the SOFA score. Then, it measure with ANOVA test methods. Infusion of albumin positively correlated with increased levels of serum albumin and a negative correlation with the levels of IL6, TNF- $\alpha$ and SOFA score. It also found a correlation between changes in levels of albumin with changing levels of IL6 ( $p<0: 01)$ and changes in SOFA score ( $p$ <0.05). (FMI 2016;52:310-315)
\end{abstract}

Keywords: sepsis, hipoalbumin, pro-inflammatory cytokines, SOFA score

Correspondence: Arie Utariani, Department of Anesthesiology \& Reanimation, Dr. Soetomo Hospital, Faculty of Medicine, Universitas Airlangga, Jalan Prof Dr Moestopo 47, Surabaya 60131.

\section{INTRODUCTION}

Sepsis is still a major problem causing high morbidity and mortality in patients hospitalized in intensive care units worldwide. in Asia, in a study by The Management of Severe Sepsis in Asia's Intensive Care Unit (mosaics) involving 150 ICUs from 16 countries in Asia reported a total of 1285 adult patients with severe sepsis who were treated in the ICU in July 2009 with a mortality rate of $44,5 \%$ (572 cases/1285 cases (Phua et al, 2011). Meanwhile, in the ICU Hospital Dr. Soetomo, the mortality rate in 2012 was $68 \%$.
Cytokines are proteins formed by cells in the body as a form of defense against infection process, wound healing and other essential functions. Although cytokines play an important role in homeostasis, the production and release of excess will cause further tissue damage and organ dysfunction (Damas et al 1992). TNF- $\alpha$, IL-1 and IL-6 is a cytokine that has a crucial role in the inflammatory process caused by infection. From research Hamishekar et al showed that IL-6 and APACHE-2 is useful in predicting mortality and clinical evaluation in patients with severe sepsis (Copper et al 2004). 
Human serum albumin (HSA) is the most numerous proteins in the body's circulation and have an important role in maintaining oncotic pressure. Exogenous HSA is a plasma substitute preparations are the most expensive. The principle use is to restore the hypovolemia and hypoalbuminemia in various pathological conditions (Vincent et al 2005). Besides the price is expensive, the use of albumin should be considered first given the risk of allergic reactions, circulatory overload, and the onset of infection because albumin is a product that could act as a mediator germs. The indications for colloid solutions do not always have to use albumin (Wei Shuen et al 2012).

Medicine, Intensive Observation Lounge (ROI) and ICU. In the final trimester of 2012 the use of albumin achieve total 406 bottles in October, rising to 567 bottles in November and 680 in December bottles. The high use of albumin has not been undertaken an evaluation of how the outcomes of patients who get it. Extent of the influence of exogenous administration of albumin on mortality of patients. By knowing the effect of albumin on mortality/morbidity of patients it is expected that we can rationally use albumin in patients treated in dr. Soetomo.

\section{MATERIALS AND METHODS}

Research conducted in the form of a prospective longitudinal observational study to analyze the use of albumin with the mortality of patients in the Intensive Care Unit (ICU) of the hospital Dr. Soetomo getting albumin infusion. The study population was all patients undergoing treatment in the intensive care unit dr. Soetomo period in February 2015 while the sample is used for patients receiving albumin infusion therapy. The inclusion criteria are samples of patients treated in intensive care since 1 February 2015 by serum albumin $<2.5 \mathrm{~g}$ with adults 14-65 years of age, with a diagnosis of sepsis. Patients were followed until death or get out of the intensive care unit. Exclusion criteria were patients who experienced an allergic reaction to previous administration of albumin, end-stage liver disease, patients with a do not resuscitate (DNR), nephrotic syndrome and patients with plasmaferesis.Besar samples used in this study were as many as 11 patients. The data collected is then analyzed statistically using SPSS

\section{RESULTS}

The number of samples in this research are 15 respondents, age of the study sample was 23-76 years with a mean of 45.3 years. Distribution of the male sex as much as 8 respondents $(53.3 \%)$ and women were 7 respondents $(46.7 \%)$. The diagnosis of a case of the respondents involved in this study are all with generalized peritonitis. Percentage obtained quite a lot of cases of generalized peritonitis due to perforation of the stomach with sepsis are 7 cases $(46.6 \%)$, where 3 of them with severe sepsis. The next most cases are generalized peritonitis due to perforation of the appendix and duodenal perforation, respectively 2 patients. And each of the other one is the case of generalized peritonitis due to rupture tuboovarial abscess, perforation of the jejunum, ileum and post relaparatomi.

Table 1. Frequency of sepsis

\begin{tabular}{lcc}
\hline & Frequency & Percentage \\
\hline Sepsis & 17 & 68 \\
Severe Sepsis & 8 & 32 \\
\hline
\end{tabular}

Table 2. Profile of study participants

\begin{tabular}{llllll}
\hline Variabel & Mean & Median & SD & Min & Max \\
\hline Age & 45.33 & 40.00 & 15.87 & 23.00 & 76.00 \\
Albumin pre & 2.12 & 2.10 & 0.09 & 2.00 & 2.30 \\
$\begin{array}{l}\text { Albumin } \\
\text { post }\end{array}$ & 2.71 & 2.70 & 0.12 & 2.56 & 2.95 \\
TNF $\alpha$ pre & 9.67 & 6.10 & 7.71 & 1.90 & 27.40 \\
TNF $\alpha$ post & 6.45 & 5.80 & 4.48 & 2.00 & 18.00 \\
IL 6 pre & 184.17 & 157.13 & 128.72 & 59.14 & 515.9 \\
IL 6 post & 110.99 & 96.80 & 95.45 & 23.06 & 417.98 \\
SOFA pre & 3,73 & 3.00 & 3.53 & 0.00 & 11.00 \\
SOFA post & 2.67 & 1.00 & 3.18 & 0.00 & 11.00 \\
\hline
\end{tabular}

From table 2 shows that there are comparisons between albumin levels before and after infusion of albumin found increased levels of albumin in the whole sample with the change value of $27.8 \%$. For examination levels of cytokines, this study examined the levels of TNF- $\alpha$ and IL6. From these results, if the comparison between the levels of TNF- $\alpha$ before and after infusion of albumin, then in almost all samples were obtained decreased levels of TNF- $\alpha$ with the value of the change of $33.1 \%$. Only two samples that showed an increase TNF- $\alpha$ level after infusion of albumin. On examination of IL6 levels obtained comparison between the levels of TNF- $\alpha$ before and after infusion of albumin, then in almost all samples were obtained decreased levels of TNF- $\alpha$ with the value of the change amounted to $39.7 \%$. Only one sample showed increased levels of IL6 after infusion of albumin.

The results of evaluation of changes in mortality by using the SOFA score, obtained a number of 6 samples 
(40\%) showed no change in SOFA scores, of which two have a SOFA score 0 both before and after infusion of albumin. The relationship between serum albumin levels IL6, TNF- $\alpha$ and SOFA scores before the administration of albumin.

To examine the relationship between levels of serum albumin with TNF- $\alpha$, IL 6 and SOFA scores used Pearson correlation test. The result is there is a significant correlation between the levels of IL6 and SOFA score $(p<0.01)$. Where the increase in IL6 levels associated with the increase in SOFA score and vice versa.

\section{The relationship between serum albumin levels with levels of IL-6, TNF- $\alpha$ and SOFA scores after administration of albumin}

To examine the relationship between levels of serum albumin with TNF- $\alpha$, IL6, and SOFA scores used Pearson correlation test. The result is there is a significant correlation between the levels of IL6 and SOFA scores used Pearson correlation test. The result is there is a significant correlation between the levels of IL6 and SOFA score $(p<0.01)$. Where rising levels of IL6 associated with kenailan SOFA score and vice versa. The relationship between changes in serum albumin levels with changes in levels of IL6, TNF- $\alpha$ and SOFA scores after administration of albumin. The result is a significant correlation between albumin infusion with changes in serum albumin levels, IL6, TNF- $\alpha$ and SOFA score. Infusion of albumin positively correlated with increased levels of serum albumin and a negative correlation with the levels of IL6, TNF- $\alpha$ and SOFA scores where after infusion of albumin obtained a decrease of three.

It also found a correlation between changes in levels of albumin with changes in IL6 levels $(p<0.01)$ and a change in SOFA score $(\mathrm{p}<0.05)$. Where the increase in serum albumin levels were negatively correlated with decreased levels of IL6 and a decrease in SOFA score. From this test also found that there is a positive correlation between changes in levels of IL6 with SOFA score as the reduction in IL6 associated with a decrease in SOFA score and vice versa.

\section{DISCUSSION}

Necrozing tumor Factor (TNF)? and interleukin (IL) 6 is an inflammatory mediators produced in the acute phase of inflammation. In this study, the mean serum TNF- $\alpha$ and IL6 both before and after getting albumin infusion does not reach the cut off point of the above research. It is likely influenced by material samples examined and therapies that have been granted (Mokart et al 2005). In this study, the correlation between serum albumin levels IL6, where a decrease in serum albumin levels will be followed by increased levels of IL6 and vice versa. Inflammatory process that occurs when the acute illness can induce hipoalbumin and inflammatory mediators can increase vascular permeability which will lead to the release of albumin in the circulation into the extravascular space (Yeun et al, 2000).

Table 3. Correlation between serum albumin, IL6, TNF- $\alpha$ and SOFA

\begin{tabular}{cccccccccc}
\hline \multirow{2}{*}{ Variables } & \multicolumn{8}{c}{ Pearson's Correlation } \\
\cline { 2 - 11 } & $\mathrm{n}$ & Albumin & $\mathrm{P}$ & TNFa & $\mathrm{P}$ & IL & P & SOFA & P \\
\hline Albumin & 15 & 1 & - & -0.441 & 0.01 & -0.111 & 0.01 & -0.187 & 0.01 \\
TNFa & 15 & -0.441 & 0.01 & 1 & - & 0.459 & 0.01 & 0.231 & 0.01 \\
IL6 & 15 & -0.111 & 0.01 & 0.459 & 0.01 & 1 & - & $0.865^{* *}$ & 0.01 \\
SOFA & 15 & -0.187 & 0.01 & 0.231 & 0.01 & $0.865^{* *}$ & 0.01 & 1 & - \\
\hline
\end{tabular}

**Positive correlation

Table 4. Correlation between serum albumin, IL6, TNF- $\alpha$ and SOFA score

\begin{tabular}{|c|c|c|c|c|c|c|c|c|c|}
\hline \multirow[b]{2}{*}{ Variables } & \multicolumn{8}{|c|}{ Pearson's Correlation } & \multirow[b]{2}{*}{$\mathrm{P}$} \\
\hline & $\mathrm{n}$ & Albumin & $\mathrm{P}$ & TNF $\alpha$ & $\mathrm{P}$ & IL6 & $\mathrm{P}$ & SOFA & \\
\hline Albumin & 15 & 1 & & -0.075 & 0.01 & 0.193 & 0.01 & 0.465 & 0.01 \\
\hline $\mathrm{TNF} \alpha$ & 15 & $-0,075$ & 0.01 & 1 & - & 0.414 & 0.01 & 0.080 & 0.01 \\
\hline IL6 & 15 & 0.193 & 0.01 & 0.414 & 0.01 & 1 & - & $0.765 * *$ & 0.01 \\
\hline SOFA & 15 & 0.465 & 0.01 & 0.080 & 0.01 & $0.765 * *$ & 0.01 & 1 & - \\
\hline
\end{tabular}

***ositive correlation 
Table 5. Correlation between albumin infusion with changes in serum albumin levels, IL6, TNF- $\alpha$ and SOFA score

\begin{tabular}{|c|c|c|c|c|c|c|c|c|c|c|c|}
\hline \multirow{2}{*}{ Variables } & \multicolumn{11}{|c|}{ Pearson's Correlation } \\
\hline & $\mathrm{n}$ & $\sum$ infus & $\mathrm{P}$ & Albumin & $\mathrm{P}$ & TNF $\alpha$ & $\mathrm{P}$ & IL6 & $\mathrm{P}$ & SOFA & $\mathrm{P}$ \\
\hline$\Sigma$ infuse & 15 & 1 & - & $0.612 *$ & 0.05 & $-0.610^{*}$ & 0.05 & $-0.739 * *$ & 0.05 & $-0.621^{*}$ & 0.05 \\
\hline Albumin & & $0.612 *$ & 0.05 & 1 & - & -0.480 & 0.05 & $-0.646 * *$ & 0.05 & $-0.621^{*}$ & 0.05 \\
\hline $\mathrm{TNF} \alpha$ & 15 & $-0.610^{*}$ & 0.05 & -0.480 & 0.05 & 1 & - & $0.618^{*}$ & 0.01 & 0.240 & 0.05 \\
\hline IL & 15 & $-0.739 * *$ & 0.01 & $-0.646 * *$ & 0.01 & $0.618^{* *}$ & 0.01 & 1 & - & $0.780^{* *}$ & 0.01 \\
\hline SÓFA & 15 & $-0.621^{*}$ & 0.05 & $-0.621^{*}$ & 0.05 & 0.240 & 0.05 & $0.780 * *$ & 0.05 & 1 & - \\
\hline
\end{tabular}

*positive correlation at 0.05

*** positive correlation at 0.01

Arie (2011) observed that increased levels of TNF- $\alpha$ and IL6 significantly in mice hipoalbumin group than in controls. This proves that the state of hipoalbumin can initiate an increase in pro-inflammatory cytokines TNF$\alpha$ as the same response in acute inflammatory or stressful situations. Van Crevel (2002) found increased concentrations of TNF- $\alpha$ and IL 1 allegedly induced by the presence of anorexia and catabolism of muscle tissue and fat that can be attributed to a decrease in BMI. The same was found by Naidoo et al (2007) there is micro-nutrient deficiency that contributes to an increase in pro-inflammatory cytokines and antiinflammatory in patients with tuberculosis.

Malnutrition as bad as in the case of inflammation affecting the concentration of albumin in which the state of malnutrition decreased acute phase protein can decrease immune function and by Amati (2003) and Brown (2003) this could lead to consequences of increased morbidity and mortality. From the results of this study found that the infusion of albumin in hipoalbumin conditions can increase serum albumin levels significantly. Albumin will be distributed in the extravascular space as a whole within 7-10 days. Approximately $10 \%$ of a given albumin infusion will move intravascular in two hours, $75 \%$ will be distributed in the extravascular space after two days. Under certain conditions, this distribution will take place more quickly (eg sepsis). In this condition, the leakage of albumin can be increased up to 13 times the normal condition (Gutrie et al 1991).

Arie (2011) observed that rats receiving albumin infusions and feeding pre-surgical preoperative normal protein can increase serum albumin levels were significantly. In the state hipoalbumin caused pathological states but still adequate nutrient inputs as well as the liver is still functioning normally, it releases thyroid hormone and cortisone that will stimulate the formation of mRNA and synthesis of albumin. Along with increased levels of serum albumin in albumin infusion is obtained decreased levels of TNF- $\alpha$ and IL6 but decreased levels of TNF- $\alpha$ was not statistically significant. Arie (2011) observed that there is a significantly positive correlation between the levels of TNF- $\alpha$, IL1 and CRP with the infusion of albumin and normal feeding protein in mice hipoalbumin decreased levels of TNF- $\alpha$, IL1 and mean CRP decreased the inflammatory process. Tai-an Chen et al (2009) conducted a study in cirrhotic patients with spontaneous bacterial peritonitis (SBP) found that the administration of albumin and antibiotics significantly reduce levels of TNF- $\alpha$ and IL6 as well as the concentration of endotoxin in the ascites fluid. Without the addition of albumin in the treatment regimen, then obtained kadarnitric oxide plasma and ascites fluid is increased in patients with SBP. The study recommends albumin infusion for 3 days in addition to antibiotics when detected the appearance of SBP in cirrhotic patients.

In this study, a significant association between changes in the mortality rate in this case SOFA score with albumin infusion, where a decline in SOFA score after administration of albumin. The relationship between hipoalbumin and poor prognosis is already known. Herrmann et al (1992) conducted a retrospective analysis of data on 15511 patients aged over 40 years who recently admitted to the ICU 48 hours. Golwasser and Fieldman (1997) estimates that every decrease in albumin $2.5 \mathrm{~g} / \mathrm{dL}$ would lead to the possibility of death by $24-56 \%$ and even death can be increased by almost $100 \%$ in the group of patients with albumin levels $2 \mathrm{~g} / \mathrm{dL}$ (Kaminski 1990) and also stated that albumin have the ability to maintain cell (cytoprotective) directly (Clark, 2001, Ginsberg 2001). Albumin has the ability to reduce the aggregation of platelets, reacts with nitric oxide to form S-nitrosolthiol, can prevent the death of cells damaged by increasing bioenergy cells through activation of pyruvat dehydrogenase. All of these capabilities to encourage the administration of albumin in brain damage (Clark, 2001, Ginsberg 2001).

A meta-analysis by Delaney et al comparing crystalloid and albumin in septic patients showed that albumin has 
its advantages. Furthermore, as well as a plasma expander, HSA has other benefits that sebag The different results obtained in the study The Sepsis Occurrence in Acutely Ill Patients (SOAP) study which showed that albumin is not always effective in all patients critical in the intensive care unit (ICU). Results of the SOAP study research even suggests there is no association between the administration of albumin with increased survival rate. The latest discovery in 2011 also showed the same thing. The discovery of the above is done on a heterogeneous population, whereas the effects of HSAs differ depending on the clinical condition.

Saline versus Albumin Fluid Evaluation (SAFE) study is a multicenter involving nearly 7000 patients showed no significant difference between the group receiving albumin $4 \%$ and the group receiving normal saline as a liquid standard resuscitation on the length of stay in the ICU, length of stay in hospitals, long use of mechanical ventilation and dialysis (Finfer et al 2004).

\section{CONCLUSION}

Infusion of albumin in septic patients with hipoalbumin can increase serum albumin levels and suppress the increased expression of proinflammatory cytokines TNF in this case? and IL6. Increased levels of serum albumin with albumin infusion is an effort to reduce the value SOFA score, which is one parameter to assess mortality, sepsis patients with hypoalbumin.

\section{REFERENCES}

Amati L, Cirimele D, Pugliese V, 2003. Nutrition and Immunity: Laboratory and clinical aspects. Curr Pharm. 9: 1924-1931

Arie, U, 2011. Disertasi: Pengaruh infus albumin pada perubahan kadar albumin serum, sitokinproinflamasi (TNF- $\alpha$, IL1, IL6), CRP, MMP8 dan ekspresio EGFR, ERK1, ERK2, TGF?, kolagen, MMP8 jaringan terhadap percepatan penyembuhan luka.

Brown P, 2003. Malnutrition Leadking Cause of Death in Post War Angola. Bull World Health Organ. 81:849-50

Clark RSB, Satchell MA, 2001. Albumin in brain injury: Not just for pressure anymore. PediatrCrit Care Med S. 38-9.

Copper BA, Penne EL, Bartlett LH and Pallock CA, 2004.Protein malnutrition and hypoalbunemia as predictor of vascular events and mortality in ESRD. Am J Kidney Dis. 43: 61-66

Damas P, Ledoux D, Nys M, Vrindts Y, De Grooned, Franchimont P, Camy M,1992. Cytokines serum level during sepsis in human: IL6 as a marker of severity. Am Surg. 215: 365-7

D. Mokart, M. Merlin, A. Sannini, J. P. Brun, J. R. Delpero, G. Houvenaeghel,V. Moutardier3 and J. L. Blache, 2005. Procalcitonin, interleukin 6 and systemic inflammatory responsesyndrome (SIRS): early markers of postoperative sepsis aftermajor surgery. British Journal of Anaesthesia vol94 (6): 767-73.

Finfer S, Bellomo R, Boyce N, French J, Myburgh J, Norton R, 2004. SAFE Study Investigators: A comparison of albumin and salinefor fluid resuscitation in the intensive care unit. $\mathrm{N}$ Engl J Med. 350:2247-2256

Ginsberg MD, Zhao W, Belayev L, Alonso OF, Liu Y, Loor JY, Busto R, 2001.High dose human albumin in markedly neuroprotection in experimental traumatic brain injury.JNeurosurg. 4(3): 499-509.

Goldwasser P, Fielman J, 1997. Association of serum albumin and mortality risk. J ClinEpidemiol. 50(6): 693-703.

Guthrie RD Jr, Hines C Jr, 1991.Use of intravenous albumin in the critically ill patient. Am J Gastroenterol ;86:255-63.

Herman FR, Safran c, Levkoff SE, Minaker KL, 1992. Serum albumin level on admission as a predictor of death, length of stay and readmission. Arch Intern Med. 152(1):125-30

Kaminski MW, William SD, 1990. Review of the rapid normalization of serum albumin with modified total parenteral nutrition solutions. Crit care med 18: 32735

Karyadi E, Dolmans WM, West CE, Van Crevel R, Nelwan RH, Amin Z, Gross R, Van Der Jongerkrijq J, Van Der Meer JW, 2007. Cytokines related to nutritional status in patients with untreated pulmonary tuberculosis in Indonesia. Asia PAC J ClinNutr. 16(2): 218-226

Thai An Chen, Yu-Chen Tsao, Angela Chen et al, 2009. Effect of intravenous albumin on endotoxin removal, cytokines, and nitric oxide production in patients with cirrhosis and spontaneous bacterial peritonitis. Scandinavian Journal of Gastroenterology Vol. 44, No. 5, Pages 619-625 (doi:10.1080/003655209 02719273)

Wei-Shuen K, Roland K, Selin S, Chipperfield K, Morrison D, 2012. Introduction of guidelines for the use of albumin and the effect on albumin prescribing practices in British Columbia.BCMJ. 54 (1): 34-38

Van Crevel R, Ottenhoff TH, Van Der Meer JW, 2002. Innate immunity to mycobacterium tuberculosis. Clinical Microbiology Reviews 15, 15: 294- 309. DOI: 10.1128/CRM.15.2.294-309.

Vincent JL, Sakr Y, Reinhart K, Sprung CL, Gerlach H, Ranien M, 2005. Is albumin administration in acutely 
ill associated with increased mortality ? Result of the SOAP study. Critical Care. 9:R745-R754

Yeun JY, Levine RA, Mantadilok V, Kaysen GA, 2000.C-reactive protein predicts all-cause and cardio- vascular mortality in hemodialysispatients. Am J Kidney Dis 35:469-76. 